\begin{tabular}{|c|c|c|}
\hline 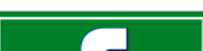 & Int.J.Curr.Microbiol.App.Sci (2021) 10(08): 653-672 & \\
\hline & $\begin{array}{l}\text { International Journal of Current Microbiology and Applied Sciences } \\
\text { ISSN: 2319-7706 Volume } 10 \text { Number } 08 \text { (2021) } \\
\text { Journal homepage: http://www.ijcmas.com }\end{array}$ & 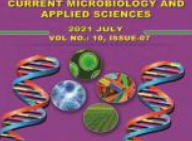 \\
\hline $\begin{array}{l}\text { EXCELLENT } \\
\text { PUBLISHERS }\end{array}$ & & \\
\hline
\end{tabular}

Review Article

https://doi.org/10.20546/ijcmas.2021.1008.075

\title{
A Review on Fungal Diseases of Cucurbitaceae and their Management
}

\author{
Thammaihraj Shanthi Avinash ${ }^{1}$, H. P. Jai Shanker Pillai ${ }^{2}$, \\ Madhuri Biradar ${ }^{3}$ and Venkat M. Shinde ${ }^{4}$ \\ ${ }^{1}$ Department of Studies in Microbiology, University of Mysore, Manasagangothri, \\ Mysore-570 006, Karnataka, India \\ ${ }^{2}$ Department of Microbiology, School of Medicine, Bridgetown International University, \\ Bridgetown, Barbados -11000 , India \\ ${ }^{3}$ Department of Post Graduate Studies and Research in Microbiology, ${ }^{4}$ Department of Post \\ Graduate Studies and Research in Botany, Gulbarga University, \\ Kalaburagi, Karnataka-585105, India \\ *Corresponding author
}

\section{A B S T R A C T}

\section{Keywords}

Gourds, Cucumber, Pumpkin, Melons, Management

Article Info

Accepted:

25 July 2021

Available Online:

10 August 2021
Cucurbitaceae is a large group of summer vegetable crops, which includes 118 genera and 825 species. India is the second largest producer of vegetables in the world with $2.8 \%$ of total cropped area and $13.38 \%$ of total vegetable production. Cucurbit is the one of the largest cash crops produced in India. These vegetables contain rich protein, carbohydrates and water to the extent of $90 \%$. Being a rich nutritious vegetable, the seeds of cucurbitaceae may contain the seed borne fungi whichwere isolated using the standard blotter method, deep-freeze method and molecular method. A wide range of pathogens affect the productivity of cucurbits. Wilt and rot are the major soil borne fungal diseases caused by Fusarium spp., damping-off by Phytophthora spp., Acremonium spp. and Pythium spp. resulting up to $70 \%$ yield loss. The moisture content of the seed, storage period, prevailing temperature and degree of seed invasion influence the development of seed-borne fungi. The pathogen may be present externally or internally or associated with the seed as contaminant. The environmental conditions support the pathogen dominance on to crop. Germination failure of seeds is mainly due to temperature, gas exchange, water activity as well as growth hormones involved in regulating germination. Biotic and abiotic factors clarify that loss of germination capacity is the final manifestation of seed deterioration.

\section{Introduction}

India is the second largest producer of vegetables in the world with $2.8 \%$ of total cropped area and $13.38 \%$ of total vegetable production (1). Being the largest cash crop, about 4,929,400 million tonnes of cucurbits were produced in India $(2,3)$. The seed health testing method reveals the percent infection of pathogens in the samples and its health. The 
study centred on developing practical and economical disease management programme to check the severity of potential fungal pathogens. The pathogen causes seed abortion and rot, necrosis, reduction, or elimination of germination capacity as well as plant damage at later stages of plant growth resulting in development of the disease as systemic or local infection (4). A wide range of pathogens affect the productivity of cucurbitaceae family (Table 1). Wilt and rot are the major soil borne fungal diseases caused by Fusarium spp., damping-off disease is caused by Phytophthora spp., Acremonium spp. and Pythium spp. resulting up to $70 \%$ yield loss. Anthracnose (Colletotrichum orbiculare), Phomopsis black stem (Phomopsis sclerotioides), Phoma blight (Phoma exigua), $\mathrm{Scab}$ (Cladosporium cucumerinum), gummy stem blight (Didymella bryoniae), Downy mildew and powdery mildews (Erysiphe cichoracearum and Pseudoperonospora cubensis), Alternaria leaf spot and leaf blight (Alternaria spp.) as well as leaf spot (Myrothecium roridum) are some of the important destructive fungal diseases of cucurbits $(5,6)$.

Totally 26 genera and 39 species of fungal colonies were isolated and identified by morphological characteristics. All the eight fungi were isolated from bottle, ridge gourd and bitter gourd seeds, cucumber and pumpkin, showed more germination as well as high rate of vigour (7). The vegetables belonging to family cucurbitaceae, brassicaceae and solanaceae are important due to their nutritional as well as economical values (8). Early blight diseases caused by fungal pathogen Alternaria spp. Inflict yield losses both in their quality and quantity of these crops. Different Alternaria spp. was found to be associated with various vegetable providing families, besides these pathogenic infections are reported due to A. tenuissima and $A$. cucumerina on cucurbitaceous plants.
Cucurbitaceae crops are sources of carbohydrates and water and their seeds are rich in oil and protein (9). Depending upon the species, virtually all parts of the plant can be used as food, including leaves, shoots, roots, flowers and seeds. Starch can be extracted from the roots, and the seeds are rich source of oils and proteins $(10,11)$.

\section{Origin}

The bitter melon (Momordica charantia) probably originated in China or India. Bitter melon is widely grown in China, India, Malaysia, Nepal, Southeast Asia, and Tropical Africa. It is grown on small acreages in the United States, primarily in California and Florida. The bottle gourd (Lagenaria siceraria (Mol. Standl.)) probably originated in Africa and from there it was widely distributed during pre-colonial times, perhaps by floating on the seas. It travelled to India, China, Indonesia, as far as New Zealand and evolved into numerous local varieties. Archaeological evidences shows that bottle gourd was used in Peru around $12000 \mathrm{BC}$, in Thailand about $8000 \mathrm{BC}$, and in Zambia around $2000 \mathrm{BC}$, Egypt about 3500 to 3300 BC. It is now cultivated in China, Europe, Haiti, Hawaii, India, Iraq, Turkey, Venezuela. Bottle gourd is cultivated throughout our country. The Cucumber (Cucumis sativas) originated in the South foot of the Himalayas in India, and later on, the plant seems to have spread eastwards to China and westwards to Asia minor. It has been in cultivation for at least 3000 years. Cucumber was grown by the ancient Greeks and Romans in about 300 BC. It was cultivated throughout Europe, almost in the middle ages. In France cucumber was common in the ninth century and in England in 1327. Cucumber was planted in Haiti and other islands along with other vegetables in 1494 by Columbus including the USA. Pumpkin (Cucurbita pepo) appears to be one of the first domesticated species. The oldest 
remains of this have been found in Mexico, in the Oaxaca valley (8750 BC to AD 700), in caves of Ocampo and Tamaulipas (7000 to $500 \mathrm{BC}$ ). Its presence in the United States also dates back to a long time, as the recordings in Missouri (4000 BC) and Mississippi (1400 BC) indicates the same. Watermelon (Citrullus lanatus (Thunb.) Matsum and Nakai), is flowering plant originally from Southern Africa. It is a large, sprawling annual creeping plant, commercial crop grown throughout the world for its sugary, fleshy edible fruit which is eaten fresh to relieve thrust especially during hot seasons. Muskmelon (C. melo L.,) is native of Iran, Anatolia, and the Caucasus, with a secondary centre including northwest India and Afganistan.

\section{Gourds}

It is a known fact that various pathogenic fungi can attack the cucurbitaceae plants and cause diseases during favourable environmental conditions, which results in yield loss. The pathogenic fungi were evaluated to study their pathogenecity on Ash gourd (Benincasahispida), Bitter gourd (Momordicacharantia), Bottle gourd (Lagenariasiceraria). The Alternaria alternata, Curvularia lunata caused the blight and rotting within 10-20 days. The fruit rot symptoms were observed on the 6th days after inoculation of Fusarium oxysporum, $F$. pallidoroseum on cucurbits (12). The seed borne fungi reported by earlier researchers includedAltenaria alternata, Botryodiplodia theobromae, Chaetomium spp., Curvularia lunata, Drechslera tetramera, Fusarium equiseti, $F$. moniliforme and $F$. solani on gourd seeds (13); on squash, muskmelon, cucumber, watermelon and bitter gourd $(14,15)$.

Cercospora leaf spot disease caused by Cercospora citrulline is one of the most important diseases of bitter gourd. Four fungicides namely benomyl, chlorothalonil, copper oxychloride, and mancozeb, were tested against the pathogen. Minimum amount of $C$. citrullina conidia germinate when treated with fungicides. It suppressed the disease and non-increasing of lesions in the leaves of bitter gourd (16). It was confirmed that the Gummy stem blight of Balsam pear (M. charantia L.,), has long been a popular vegetable in the Okinawa area (17). The disease-causing lesions on leaves, stems, and fruit were found in fields and gardens. Based on inoculation experiments, molecular analysis, and morphological identification, the imperfect stage of the fungus was identified as P. cucurbitacearum (Fr.: Fr.) Sacc.. Leaves had light brown, irregular lesions and later became torn. Pycnidia and pseudothecia were present as small black spots on leaves, stems, vines, and fruits withered away.

A total of 15 genera and 29 species of seed borne fungi of bittergourd were isolated by both blotter method and deep-freezing method in Pakistan. Among them, the leaf spot (Cercospora spp., and Myrothecium roridum), Powdery mildew (Oidium sp.), white rot of fruit (Sclerotium rolfsii) and Rizoctonia solani fruit rot, Fusarium spp., and Penicillium purpurogenum were predominant (18). The infestation of leaf spot of bitter gourd grownin the districts of Khyber Pakhtunkhwa during 2010 was reported. The highest (20.4\%) infestation of leaf spot of bitter gourd were reported from Jabba Daudzai, while the lowest (19.5\%) from Nasirpur, Tailmalpura and Yaseen Abad(19). The in vitro association of seed borne fungi of bitter gourd seeds collected from southern regions of Punjab province was studied and the tests were conducted in Bahauddin Zakariya University, Pakistan. Six fungal species were isolated, out of which Aspergillus flavus showed highest percentage $27.3 \%$ followed by Rhizopus stolonifer $17.98 \%$, Alternaria alternata 
$13.34 \%$, A. niger $5.23 \%$, Myrothecium roridum $7.37 \%$ and Fusarium solani $6.69 \%$. More number of fungi was observed by using blotter paper technique when compared with agar plate method (20).

Myrothecium sp., M. roridum Tode ex Fr. and M. verrucaria (Alb. Schew) Ditm ex Fr., are soil borne as well as seed borne pathogens and attack several plant species causing leaf spot / blight pathogen of cucurbits. M. roridum isolated from seeds of bittergourd, bottlegourd, Indian gourd, red gourd, sponge gourd, pumpkin, and melon. Myrothecium sp., generally cause round dark-brown leaf spot in cucurbits, later stage coalesces to form blighted areas on the leaves, reduced seed germination and caused seed rot, damping off, root rot and spots on aerial parts. The disease can reduced by the fungicide spray on the leaves (21). In Tiwan seedling blight of bittergourd caused by Alternaria alternate f. sp. cucurbitae was predominant in grafted seedlings at the temperature of $8-16^{\circ} \mathrm{C}$. The mycelial growth was controlled by the fungicides like mancozeb, pyrifenox both in nursery and on water agar (22). Pathogenicity and aggressiveness of $F$. oxysporum in bitter gourd and bottle gourd isolated from two breeding stations in the Philippines. Eleven $F$. oxysporum isolates from bitter gourd and 12 isolates from bottle gourd were inoculated, on 7-day and 1-month-old bitter gourd and bottle gourd plants in the greenhouse. All the $F$. oxysporum isolates from bitter gourd and bottle gourd were pathogenic. Aggressiveness of pathogenon 7-day-old bitter gourd and bottle gourd was moderate compared to those on 1-month-old plants ( $r=0.63,0.78)$ (23).

Bottle gourd seeds naturally infected with $F$. oxysporum appeared with or without white crust. The incidence of symptomatic seeds in Rajasthan varied from $1.25-26.75 \%$. On inoculation, the pathogen was isolated from $33 \%$ samples with $1-42 \%$ incidence in chlorine pre-treated seeds. Mycelium in asymptomatic seeds was extra-embryonal and confined to seed coat only; but it occurred in seed coat, aleurone layer, cotyledon, and embryonal axis of symptomatic seed. The infection resulted in transmission of disease from the inoculum present in seed coat to other part of the seedling; whereas, intraembryonal infection mostly caused preand post-emergence losses (24). The survival of Lasiodiplodia theobromae in seeds of bottle gourd was depend on the inoculum level of the fungus on seeds. Survival of M. phaseolina on seeds of bottle gourd and cucumber varied and up to $50 \%$ and was recorded after 5 and 6 months of storage. Alternaria spp., Cladosporium spp., and Fusarium spp., decreased after 3-6 months of storage whereas A. flavus and A. niger were most frequent after 6 till 24 months of storage. The pathogens were influenced by external and internal factors, up to period they colonize the $\operatorname{seed}(25)$.

Thirty-seven species within Cucurbitaceae representing the genera Citrullus, Cucumis, Cucurbita, Lagenaria, and Luffa was evaluated and the disease reaction to an Acremonium cucurbitacearum was also studied in Texas. After 28 days in the greenhouse, seedling disease ratings were made on the hypocotyl, stem-root junction, primary root, and secondary roots. Vine and root dry weight were poor due to plant damageby A. cucurbitacearum (26). Most of the fields in costal region of Spain was infected with a new disease of muskmelon (Cucumis melo) Acremonium species after fruit ripening. Root symptoms appear soon after planting were yellow discoloration and corking of upper roots (27).

The Fusarium species as one of the most common fungal species causing post-harvest diseases such as fruit $\operatorname{rot}(28,29)$. The vegetable fruits sampled were cucumber $(C$. 
sativus), loofah (L. acutangula) and bitter gourd (M. charantia). Fifty-two Fusarium isolates were obtained and identified by morphological characteristics, out of which the three important species were namely, $F$. semitectum, $F$. oxysporum and $F$. equiseti. The most common species isolated were $F$. semitectum $(33 \%)$ followed by $F$. oxysporum $(27 \%)$. The presence of several Fusarium species suggested that vegetable fruits are prone to Fusarium contamination. In gray mold disease of Sponge Gourd (L. cylindrica) caused by Botrytis cinerea, the symptoms appear as small, brown spots that spread to the entire flower within 2-3 days. The pathogen develops abundant mycelium and the fruits causing blossom ends in rot, fruit, stem also rottens and infected fruits become completely rotten. The conidia were smooth, hyaline, and globoid. The identity of $B$. cinerea was confirmed by the production of numerous black sclerotia on PDA plates. Pathogenicity tests proved the similar symptoms of gray mold disease on shrubs and nursery plants and it is the common pathogen in Central Taiwan (30).

\section{Cucumber}

The world is facing 70-100\% yield losses of Cucumbers due to infection by Fusarium spp. In India alone the loss is estimated at above $70 \%$ of the yield due to the soil-borne diseases $(31,32)$. Seed borne infection and germination of seeds of 7 vegetables viz. amaranth, red amaranth, spinach, okra, cucumber, tomato and eggplant were tested and 11 fungi were detected which were Alternaria spp., Aspergillus flavus, A. niger, Phomopsis vexans, Curvularia spp., Fusarium spp., Penicillium spp., Rhizopus spp., Colletotrichum dematium, Macrophomina phaseolina and Cladosporium spp. Among the four fungi in cucumber $13.50 \%$ of fungal infection seen in seeds and the highest percent germination was recorded in cucumber $87 \%$
(33). Alternaria cucumerina and Trichoderma harzianum infection to the cucumber cultivars confirms the infected and susceptible cultures (34). Severe attacks of Phytophthora spp., Pythium spp., Botrytis cinerea, Didimella lycopersici, Alternaria spp. and Cladosporium fulvum occurrs annually on Solanaceae and cucurbits mainly focused with cucumber, melon, and zucchini as main crops in farms. Pseudoperonospora cubesis were frequently seen on the green house cucumbers. Crown rots and root rot diseases are frequently seen in the field and greenhouse (35). In the survey, eight greenhouses were infected with the crown rot of the Fusarium. The damage estimated is above $75 \%$ severe and based on the stem lesions, sporodochia produced with vascular discoloration. On the basis of the conidia, phialides, and chlamydospores the fungi identified as $F$. oxysporum. The pathogencity tests were done at pregermination, 1or 2 true leaves and more than 10 leaves stage on the cucumber, watermelon, zucchini and loofah. The symptom shows the wilt, yellowing and vascular discoloration confirming the $F$. oxysporum f. sp. Cucumerinum(36). The disease symptoms were identical to the Fusarium roots and stem rot of cucumber ( $C$. sativus L.). The disease was confirmed in all of the 21 surveyed cucumber-growing areas dispersed in the North, South and West of Bulgaria. A paleyellow lesion on the stem base was often the first disease symptom later necrosis progressively expanded until the entire crown area and basal part of the stem partly disintegrated into light orange-brown rot in 68 weeks after sowing. Under moist conditions, the rotten tissues were overgrown with white mycelium, later became pinkish-orange due to external spore formation of $F$. oxysporum. The infected plants suddenly wilted, collapsed and died. Examination of the roots revealed yellowish-brown discoloration and rot of the cortex and xylem. The pathogen was identified as $F$. oxysporum f. sp. radicis- 
cucumerinum on the basis of symptoms, experimental hosts range among plant species of cucurbitaceaae, cultural and morphological characteristics of the obtained isolates (37). The Alternaria cucumerina and A. alternata infect almost all cucumbers worldwide as well as the spores are transported by wind over long distances through rain. The warmth and humidity (60-80\%) are favourable for the onset of infection and disease development (8). Anti-fusarium activity of Streptomyces spp. was examined against the root rot and wilt diseases in greenhouse cucurbits in Kerman province of Iran. S. olivaceus reduce the crop losses by the pathogen (38). A root and stem rot disease was observed on greenhouse-grown cucumber plants $(C$. sativus) in the Antalya, Turkey. A yellowishbrown discolouration of the vascular tissues and rotting of the leaves, roots and stem with $10 \%$ wilting of plants. The fungus produced abundant microconidia in false heads on simple phialides and macroconidia were threeseptate. Chlamydospores and orange sporodochia formed on PDA media and the fungus was identified as Fusarium oxysporum. Pathogenicity tests were done on cucumber plants after three weeks of inoculationshowed severe root rot and stem rot symptoms and the plants were died. Pathogens survive in soil and seed in the form of chlamydospores for many years. Cucumis melo and Citrullus lanatus plants showed the same symptoms and pathogen was re-isolated from diseased plants $(29,39)$.

The root and stem rot of greenhouse cucumber was observed in British Columbia and increased the frequency and severity. Wilted plants showed the orange spore masses on crowns and roots of the plant cortical and vascular tissues. The pathogen reported in muskmelon, squash, watermelon, and gourd developed root and stem symptoms similar to those on cucumber when examined by root dip method (40). Melon, cucumber, and squash samples showed powdery mildew pathogen Sphaerotheca fuliginea majorly in Sudan. In field tests $S$. fuliginea race 1 observed in summer and race 2 in winter season. Virulence test shows the races occur eventually (41).

Phytophtora spp shows most destructive diseases of cucumber, these pathogens causes damping-off, crown and root rot, stem lesions, foliar blight, and fruit rot. This pathogen infects susceptible hosts throughout the growing season and survives as dormant oospores during the winter (42). The cucumber damping in greenhouses during 2006-2007 in Iran was reported (43). The soil samples and root samples collected, the plants with leaf yellowing, wilting or crown rot were analysed. The total of 151 isolates obatined from the samples belonging totwo genera and five species (Phytophthoradrechsleri, $P$. melonis, Pythium aphanidermatum, $P$. irregulare and $P$. ultimum) were found to be predominant in the region.

The root-knot nematodes (Meloidogyne spp.) were recorded with varying degrees in cucumber fields across season, 378 randomly selected sites in 126 villages of the four districts across the Pothowar zone. The incidence of root-knot nematodes was recorded highest in Rawalpindi district $(21.86 \%)$ and minimum $(6.94 \%)$ in Kotlisattian. In overall root-knot severity and distribution, $M$. incognita $(74.17 \%)$ was the most prevalent followed by $M$. javanica (21.69\%), M. hapla (1.81) and $M$. arenaria $(2.33 \%)$. M. incognita as a pure population was recorded in $29.63 \%$ of the villages, while the other was found as mixtures $(44,45)$. The incidence and distribution of root knot nematodes in vegetable production area of Taxila was also reported (46). Meloidogyne spp. were determined in survey in both the open-field and plastic tunnel planted cucumber crop. M. incognita was predominating with $95 \%$, occurrence and the 
roots of plants within tunnels showed $3.85 \%$ and $7.14 \%$ of greater gall and egg mass indicesrespectively over that of open-field plants.

A. alternata, C. tenuissimum, Botrytis cinerea, F. solani, Corynespora cassicola, Aspergillus, Curvularia and Bipolaris are isolated from the diseased cucumber fruits collected from greenhouses in Oman. Comparing the efficacy of foliar and soil applications of carbendazim fungicide on fruit rot of cucumber showed that foliar applications significantly reduced fruit rot and increased cucumber yield when compared to soil application or to untreated experimental controls(47). Sclerotinia blight disease of cucumber (2.8\%) and pepper (3.3\%) plants were surveyed in the plastic houses in the protected cultivation station, Tookh province, Qalubiya governorate, Egypt. The fungus $S$. sclerotiorum and $S$. minor causes foliage blights of the both crops. Both the pathogens are inhibited in-vitro by using fungicides Topsin-M and Ridomil Gold and biocontrol agents. Tichoderma spp. showed superior inhibitory effect against the growth of pathogenic fungi compared with $B$. subtilis and P. Florescence (48). The root and shoot fungal diseases in their survey in high vegetable producing areas in Egypt was surveyed (49). In the vegetables, cucumber showing damping off, root rot and wilt symptoms. The root fungal pathogens isolated from rhizospheric soil were recorded in high frequency and it includes Phythium spp., Fusarium spp., Rhizoctonia solani, Macrophomina sp, Sclerotinia spp., and $S$. rolfsii. All the pathogens tested against bioagents, resulted in disease reduction. The greenhouse soil drenched with bioagents showed reduction in root rot incidence in cucumber and cantaloupe.

Fungal pathogens; Fusarium oxysporum, F. solani, Sclerotium rolfsii, Rhizoctonia solani and Macrophomina phaseolina were isolated from the damping off samples of the diseased cucumber fields in El-Behera Governorate during survey. Among them $F$. oxysporum $(23 \%)$ was frequently recovered. Americana Beta Alpha, Americana IBB Beta-Alpha, Denmark Beta-Alpha and non-inoculated control were checked for their efficacy against the damping-off. Mycelial growth of the $F$. oxysporum, $F$. solani and $S$. rolfsii was inhibited by the extracts of garlic and onion. The Denmark Beta-Alpha showed highest disease susceptibility and Americana BetaAlpha showed the lowest (50).

The characterization of Pythium aphanidermatum as the main causal agent of damping-off in Oman was studied and characterized (51). The concentration of $\mathrm{NaCl}$ required to reduce growth of $P$. aphanidermatum isolates by $50 \%$ varied from 23 to $62 \mathrm{dSm}^{-1}$, with an average of $46 \mathrm{dSm}^{-1}$, however, oospore production was more sensitive to salinity and no oospores were produced above $20 \mathrm{dSm}^{-1}$. The major vegetables cucurbits, chilli, okra, tomato, brinjal and cauliflower growing areas of Gangatic planes covering in the Uttar Pradesh, India was surveyed (52). The study revealed the 44 fungal diseases, seven bacterial and eight viral diseases of the vegetables. Among them the highest severity of disease on different crops were seen on Alternaria blight of tomato with $15-90 \%$, on cucurbits downy mildew (10-80\%) and anthracnose (35-90\%), Phomopsis bilght of brinjal (10-70\%), leaf blight of okra (25-85\%) and damping off of the nursery crops (30-85\%).

\section{Pumpkin}

Pumpkins can be infected by fungal, bacterial, and viral pathogens from the time of fruit set until harvest. Major fruit rots of pumpkins are Phytophthora rot (P. capsici), Fusarium rot (Fusarium spp.), bacterial spot (Xanthomonas campestris pv. cucurbitae), black rot (D. 
bryoniae), and Sclerotinia rot $(S$. sclerotiorum). Phytophthora rot, caused by the oomycete $P$. capsici Leonian, is one of the most serious threats to the production of pumpkins and other cucurbits throughout the world. 49 plant species can be infected by $P$. capsici to watermelon (Citrullus lanatus), cantaloupe and honeydew melon (C. melo), cucumber (C. sativus), blue Hubbard squash (C. maxima), Cucurbita pepo varieties including acorn squash, gourd, pumpkin, yellow squash, zucchini squash, and processing pumpkin (C. moschata). The pathogen also infects seedlings, leaves, vines, crown and produces numerous sporangia on infected fruit. Growth patterns of colonies are cottony, petaloid, rosaceous, and stellate.

Sporangia of $P$. capsici are variable subspherical, ovoid, obovoid, ellipsoid, fusiform, pyriform and papillate with a long pedicel. Zoospores are produced inside sporangia and are biflagellate. The pathogenis a soilborne and survives between crops as oospores in soil or mycelium in plant debris, Oospores are resistant to desiccation, cold temperatures, and other extreme environmental conditions. The total loss of the crop results are due to phytophthora foliar blight and fruit rot (53). Fusarium fruit rot is one of the most common pre- and post-harvest diseases of pumpkins, as well as of other cucurbit crops. The pumpkin growing fields in the Ohio state during 2001-2002 for the rot disease of Fusarium was surveyed (54). From the 23 farms of six counties, 164 Fusarium isolates were collected. Fusarium oxysporum, $F$. solani, $F$. graminearum and $F$. acuminatum were the important pathogens mainly identified from the diseased fruits. On the basis of the symptoms on fruits, the pathogens were characterized into the Type1 primary stage, Type2 rot stage and Type3 rot secondary stage. Among them F. solani was more pathogenic with racel and race 2 which causes the rot.
The fungus Alternaria cucumerina has been found in the Far Eastern region of Russia on C. melo, C. sativus and C. lanatus. Leaf blight of pumpkin (C. maxima) was accompanied by powdery mildew in private gardens located in the Republic of Dagestan. The observed leaf spots were up to $8-12 \mathrm{~mm}$ in diameter with a round greyish to pale brown centre and dark brown edges. Up to $30 \%$ of the surface area of older leaves was affected by the disease. Fungal isolates with morphological characteristics similar to those of $A$. cucumerina were collected from diseased leaves and cultured on V4 medium then incubated at $24^{\circ} \mathrm{C}$ under a light/dark cycle $(12 / 12$ h). After seven days, large solitary conidia were formed on the surface of the agar (55). A number of Fusarium species, including $F$. graminearum, $F$. acuminatum, $F$. culmorum, $F$. moniliforme, $F$. semitectum, $F$. equiseti, F. scirpi, and $F$. solani, have been reported as causal agents of cucurbit fruit rot. Symptoms on fruit rot of pumpkins were small, crater or corky spots to large, sunken areas covered with a white or gray mold. If the soil is removed from around the base of the plant, a very distinct necrotic rot of the crown and the upper portion of the taproot are evident. The Initial symptom of crown rot, entire affected plant usually wilts, collapses, and dies within 2 to 4 weeks $(5,56)$.

Black rot disease is caused by fungus $D$. bryoniae (Auersw.) Rehm (anamorph Phoma cucurbitacearum (Fr.:Fr.) Sacc.). Black rot is an important pre and postharvest fruit rot of pumpkins and winter squashes. Symptoms of black rot can appear in the field before harvest and continue to develop during transit as well as in storage. Small, water-soaked, dark brown lesions develop and enlarge on fruit. As the lesions expand, they become blackened pycnidia on fungal tissue. Affected fruit may collapse during or after harvest. D. Bryoniae and $P$. cucurbitacearum produces dark pseudothecia, globose, immersed, becoming 
erumpent, opening by apical papillate ostiole. It produces numerous bi nucleiate asci, cylindrical to subclavate, short stipitate or sessile, with eight ascospores per ascus, ascospores are hyaline, ellipsoid, with rounded ends, monoseptate and slightly constricted at the septum. Pycnidia of $D$. bryoniae on the surface of infected tissues was isolated from the seed coat, perisperm, and cotyledons of cucumber and pumpkin seed produced in several countries in Asia, Africa, and Europe (53). Thepycnidia containing $\alpha$ spores from the Japanese isolate of Phomopsis sp. obtained from a diseased pumpkin root was described (57). In phylogenetic analyses of rDNA-ITS regions, nine isolates of Japanese Phomopsis sp. from melon, watermelon grafted onto bottle gourd, and pumpkin diagnosed with black root rot, formed a single clade with $P$. sclerotioides standard isolates. The causal agent of the black root rot of melon, pumpkin, bottle gourd, and watermelon in Japan as $P$. sclerotioides was identified. Patterns of random amplified polymorphic DNA (RAPD) of these Japanese isolates were also found to be similar to those of $P$. sclerotioides, thus supporting the species identification.

The fungal isolates of Alternaria tenuis, Aspergillus niger, F. oxysporum, F. solani and Rhizoctonia solani from diseased squash roots was studied. Pathogenicity tests proved that squash plants were highly vulnerable to attack by $F$. solani and $R$. solani during the pre- and post-emergence stages. The in-vitro antagonistic effect of Trichoderma harzianum showed highest mean inhibition values which were against $F$. solani $(78.86 \%)$ and $R$. solani (41.94\%), respectively. In-vitro, benlate fungicide was found to be very toxic to the root-rot pathogens. Soil or seed coated with $T$. harzianum and benlate had a significant lower percentage of infection and significantly longer in height and better plant growth parameters. Nine fruit and vegetable samples Allium cepa, Solanum lycopersicum, Solanum tuberosum, Citrus aurantifolia, C. sativus, $C$. pepo, Fragraria grandiflora, Psidium guava and Citrus reticulata were collected from markets in Aswan city. Nine fungal genera with more than fifteen species were isolated. Among them Aspergillus spp. were major fungi isolated, followed by the Acremonium, Fusarium, Alternaria, Penicillium. The A. flavus and $F$. proliferatum produced clear zone in the CMC media to give cellulase enzyme (58).

\section{Melons}

The sporodochia of $M$. verrucaria were observed maximum in the watermelon samples from both seed-borne and soil-borne fungi. Spore suspension of pathogen was inoculated to healthy watermelon seeds as well as seedlings showed the symptoms of the disease confirming the disease both seedborne and soil-borne fungi (59). Myrothecium roridum is an important pathogen of seven samples of diseased plants of cucumber $(C$. sativus), gherkin ( $C$. anguria) and squash $(C$. moschata) showing the leaf spots which were collected in Amazonas State, Brazil. Fungal isolates were isolated and identified as $M$. roridum, with phialide and conidia. Pathogenicity of these isolates was tested on wounded and non-wounded leaves of gherkin, cucumber, squash, pumpkin, watermelon, and melon plants. All isolates showed a slight variability in their aggressiveness (60).

Area of lesions produced by Colletotrichum orbiculare on watermelon seedlings was not affected by amount of culture medium on which the fungus was grown and decreased as length of time the fungus was culture. Internal integrity of $C$. orbiculare spores appeared degraded, and this was coincident with decrease in the lesion(61). Foliar, stem, and fruit lesions were observed on watermelon $(C$. lanatus (Thunb.) Matsum.\& Nakai) and pumpkin (C. maxima Duchesne) in the district 
of Arusha, Tanzania during the warm, rainy season. Similar symptoms were observed in commercial watermelon and pumpkin fields with as much as $100 \%$ fruit loss in watermelon. Disease symptoms on watermelon and pumpkin were brown, Vshaped leaf lesions, stems showed watersoaked lesions after rain, which dried up and cracked. On pumpkin, a gummy, amber exudate was seen after rain on stem and fruit lesions. Flowers and fruits of both hosts developed black rot spots and aborted (62). The fungal species $M$. verrucaria, $D$. bryoniae, $F$. oxysporum and $F$. solani were found to be highly pathogenic under field condition. The severities of infection showed varied degree of leaf spots, blight, gummy stem blight and wilt; which decreased the percentage of seed germination, seedling vigour, and reduced the yield of the crop. In the tested fungicides, Topsin and M-45 were positive against the leaf spot as well as gummy stem blight (63).

Muskmelon (C. melo cv. Temprano Rochet) and autumn squash (C. maxima) seedlings were inoculated either with Acremonium cucurbitacearum or Monosporascus cannonballus, two of the soil-borne fungi implicated in 'melon collapse'. Pathogenicity was tested by growing the plants in pots containing infested soil and seedlings in petri dishes together with fungal colonies in order to observe the colonisation. Both muskmelon and autumn squash roots infected with $A$. cucurbitacearum showed a suberised layer in the epidermis and the outermost layers of the parenchymatic cortex. $M$. cannonballus infection showed only a slight increase in the size of cortical intercellular spaces of the lower stems of muskmelon plants and infected autumn squash tissues remained free of these symptoms. The xylem vessel, lumina of both muskmelon (susceptible) and autumn squash (resistant) showed hyphae and tylose formation as a result of fungal infections (64).
In Coastal region of Spain, a new disease of muskmelon (C. melo) was observed. Most of the fields were infected with the Acremonium species after fruit ripening; root symptoms appear soon after planting and include yellow discoloration and corking of upper roots (27).

The pathogen, that infected watermelon seedlings collected from the greenhouses of Naju and Kwangsan of Korea was observed (65). Infection sites were initiated with sunken and dark green spots and coalesce. Leaf stalk of seedlings were infected and softened with gummy substances, upper parts of seedlings were broken down, dried and eventually died. Conidiophores of the fungus were characterized by pale olivaceous brown color, branched chains, ellipsoidal, fusiform, and single cell without septum. On the morphology of the spore the fungal colonies were identified as the Cladosporium cucumerinum, which showed variable symptoms on all cucurbitaceous members causing scab. A severe root and stem rot disease of melon was observed during the 2001 growing season on four glasshouse crops in Heraklio, Greece. A total of 43 isolates of $F$. oxysporum, obtained in Crete from glasshouse-grown melon and showing Fusarium wilt or root and stem rot symptoms in Greece, and were characterized by pathogenicity and vegetative compatibility. The majority of these isolates were also fingerprinted via amplified fragment length polymorphic (AFLP) analysis. Of the total number of isolates, 22 were identified by pathogenicity tests as $F$. oxysporum f. sp melonis, 20 as $F$. oxysporum f. sp. radiciscucumerinum, while one isolate was nonpathogenic on cucumber, melon, sponge gourd and pumpkin(66).The genetic diversity among 50 melon landraces; collected from 3 agroecological regions of southern India was studied (67). Melon germplasm with high titrable acidity, higher than average amounts of mineral content and resistance to Cucumber 
mosaic virus, Zucchini yellow mosaic virus, Powdery mildew (races 1, 2, 3, 5), Fusarium wilt (races 1,2), Aphis gossypii and leafminer was recorded.

Muskmelon (C. melo L., var. cantalupensis) plants grown from seed in sand infested with the rootrot pathogen $M$. cannonballus, $A$. cucurbitacearum, $R$. vagum were observed after 28 days in the growth chamber. In comparison to uninoculated muskmelons, inoculated plants had significantly increased mean root diameter $(45 \%)$, decreased root length $(26 \%)$, decreased number of root tips (27\%), decreased rhizosphere volume (40\%) and mean surface area of leaves (24\%). Multivariate analyses of plant responses were more powerful than univariate analyses to differentiate among effects of pathogen species and pathogen isolates. Digital image analyses proved useful to identify groups of plant traits modified by each fungal species or isolate at low disease levels (68). In Italy, recent years melon has been subjected to significant losses in yield and quality due to an increasing number of soil-borne fungal diseases. $M$. cannonballus, $A$. cucurbitacearum, Plectosporium tabacinum and $R$. vagum were a complex of fungal pathogens representing one of most destructive diseases worldwide. The RFLP sequence data analysis shows homologues identity in $M$. cannonballus. In pathogenicity tests under greenhouse conditions $M$. cannonballus, A. Cucurbitacearum and $P$. tabacinum caused collapse symptoms and root rots, whereas $R$. vagum was found to be a weak pathogen (69). Melon root rot and vine decline caused by $M$. cannonballus was common in hot, semi-arid melon-growing areas of Israel, India, southern Spain, southwestern regions of the United States. Monosporascus wilt, with an emphasis on the potential for integrated management approaches include, breeding for resistance, grafting melon plants onto resistant Cucurbita and melon rootstocks, changes in irrigation schemes, improved soil solarization, chemical control with fungicides, and the use of other fumigants, alone or combined with soil solarization, to improve disease control (70). Muskmelon ( $C$. melo) seedlings showing disease include stem necrosis with an exudation of gummy material, angular watersoaked lesions on the leaves and rotten fruits from the fields of Karnataka, India. The mucus dried on the stem forming a black pycnidia and white aerial mycelia was observed on the stems, leaves and fruits.

Conidia were hyaline, cylindrical with rounded ends, nonseptate, but a few are septate in winter lie dormant and can survive in the soil surface (71 - 73). Gummy stem blight is a major foliar disease of muskmelon (C. melo L.) The morphological characteristics and rDNA internal transcribed spacer (ITS) sequencesof musk melon was analysed to identify the causal organism. Nucleotide sequences of the rDNA ITS region from pure culture ranged from $98.2 \%$ to $99.8 \%$. Phylogenetic analysis with related species of $D$. bryoniae revealed that $D$. bryoniae is a monophyletic group distinguishable from other Didymella spp., Mycosphaerella pinodes, $M$. zeae-maydis, $D$. pinodes, $D$. applanata, D. exigua, D. rabiei, D. lentis, D. fabae, and $D$. vitalbina. Phylogenetic analysis, based on rDNA ITS sequence, clearly distinguished D. bryoniae and Didymella spp. from the 10 other species studied. D. bryoniae has a broad host range, causing conditions viz. black rot, gummy stem blight, leaf spot, and stem canker (72). The gummy stem blight (D. bryoniae) and the downy mildew (Pseudoperonospora cubensis) are two melon (C. melo) diseases, considering their effects on yield and fruit quality in Brazil. 
Table.1 Important Cucurbitaceous diseases and their causal agents $(6,86)$

\begin{tabular}{|c|c|}
\hline Disease & Causal Agent \\
\hline \multicolumn{2}{|r|}{ Fungal diseases } \\
\hline Alternaria leaf blight & Alternaria cucumerina \\
\hline Alternaria leaf spot & Alternaria alternata f.sp. cucurbitae \\
\hline Anthracnose & Colletotrichum orbiculare \\
\hline Belly rot & Rhizoctonia solani \\
\hline Blue mold rot & Penicillium spp. \\
\hline Root and dieback & Acremonium spp. \\
\hline Crown and foot rot & Fusarium solani \\
\hline Damping-off & $\begin{array}{l}\text { Fusarium spp., Fusarium equiseti } \\
\text { Pythium spp. }\end{array}$ \\
\hline Fusarium wilt & $\begin{array}{l}\text { Fusarium oxysporum (with these formae pecials) } \\
\text { Fusarium oxysporum f.sp. cucumerinum } \\
\text { Fusarium oxysporum f.sp. lagenariae } \\
\text { Fusarium oxysporum f.sp.luffae } \\
\text { Fusarium oxysporum f.sp.melonis } \\
\text { Fusarium oxysporum f.sp.momordicae } \\
\text { Fusarium oxysporum f.sp. niveum }\end{array}$ \\
\hline Gray mold & Botrytis cinerea \\
\hline Gummy stem blight & Didymella bryoniae \\
\hline Phoma blight & Phoma exigua var. exigua \\
\hline Phomopsis black stem & Phomopsis sclerotioides \\
\hline Phytophthora root rot & Phytophthora spp. \\
\hline Powdery mildew & Sphaerotheca fuliginea and Erysiphe cichoracearum \\
\hline Downy mildew & Pseudoperonospora cubensis \\
\hline Scab & Cladosporium сиситеrinum \\
\hline Verticillium wilt & Verticillium albo-atrum, Verticillium dahlia \\
\hline \multicolumn{2}{|r|}{ Bacterial diseases } \\
\hline Angular leaf spot & Pseudomonas amygdali pv. Lachrymans \\
\hline Fruit blotch/seedling blight & Acidovorax avenae subsp. Citrulli \\
\hline Bacterial soft rot & Erwinia carotovora subsp. Carotovora \\
\hline \multicolumn{2}{|r|}{ Viral diseases } \\
\hline Cucumber green mottle & Cucumber green mottle mosaic virus (CGMMV) \\
\hline Cucumber mosaic & Cucumber mosaic virus (CMV) \\
\hline Cucumber vein yellowing & Cucumber vein yellowing virus (CVYV) \\
\hline Melon leaf curl & Melon leaf curl virus (MLCV) \\
\hline Squash mosaic & Squash mosaic virus (SqMV) \\
\hline Zucchini yellows & Zucchini yellows mosaic virus (ZYMV) \\
\hline
\end{tabular}


Table.2 Fungicides with label rates, chemical component, class and mode of action $(80,81)$

\begin{tabular}{|c|c|c|c|c|}
\hline Fungicides & $\begin{array}{l}\text { Highest label } \\
\text { rate }\end{array}$ & Component & Chemical class & Mode of action \\
\hline Ridomil Gold & 1.46kg a.i./ha & $\begin{array}{l}\text { Mefenoxam } \\
\text { Chlorothalonil }\end{array}$ & $\begin{array}{l}\text { Phenalymide } \\
\text { Substituted benzene } \\
\text { Substituted aromatic }\end{array}$ & $\begin{array}{l}\text { Depresses nucleic acid synthesis } \\
\text { Combines with } \mathrm{NH}_{2} \text { or } \mathrm{SH} \text { group } \\
\text { of essential metabolic compounds }\end{array}$ \\
\hline Bavistin & $500 \mathrm{~g}$ a.i./ha & Carbendazim & Benzimidazole (MBC) & Inhibits formation of microtubule. \\
\hline Kavach & $2.40 \mathrm{~kg}$ a.i/ha & Chlorothalonil & Substituted benzene & $\begin{array}{l}\text { Combines with } \mathrm{NH}_{2} \text { or } \mathrm{SH} \text { group } \\
\text { of essential metabolic compounds }\end{array}$ \\
\hline Thiram & $1.87 \mathrm{~g}$ a.i/ha & Thiram & $\begin{array}{l}\text { Phenalymide } \\
\text { Dithiocarbamate }\end{array}$ & $\begin{array}{c}\text { Interferes with oxygen uptake and } \\
\text { inhibits sulphur containing } \\
\text { enzymes }\end{array}$ \\
\hline Quadris & $112.09 \mathrm{~g}$ a.i/ha & Azoxystrobin & Pyridimine & Inhibits biosynthesis; sterols \\
\hline Bravo Ultrex & $2.40 \mathrm{~kg}$ a.i/ha & Chorothalonil & $\begin{array}{l}\text { Substituted benzene } \\
\text { chloronitrile }\end{array}$ & $\begin{array}{l}\text { Combines with } \mathrm{NH}_{2} \text { or } \mathrm{SH} \text { group } \\
\text { of essential metabolic compounds }\end{array}$ \\
\hline Manzate 75DF & $2.52 \mathrm{~kg}$ a.i/ha & Mancozeb & $\begin{array}{c}\text { Ethylene } \\
\text { bisdithiocarbamate }\end{array}$ & $\begin{array}{c}\text { Inactivates } \mathrm{SH} \text { groups in amino } \\
\text { acids. }\end{array}$ \\
\hline
\end{tabular}

Table.3 Biocontrol agents, with their host species used against the diseases

\begin{tabular}{|c|c|c|c|}
\hline Sl. No. & Isolate & Crop & $\begin{array}{l}\text { Target Disease / } \\
\text { Organism }\end{array}$ \\
\hline 1 & Ageobacterium radiobacter strain 84 & $\begin{array}{l}\text { Ornamentals, } \\
\text { Fruits, Nuts }\end{array}$ & $\begin{array}{l}\text { Agrobacterium } \\
\text { tumefaciens }(87)\end{array}$ \\
\hline 2 & Bacillus subtilis, Paenibacillus polymyxa & Melon & Fusarium wilt (88) \\
\hline 3 & $\begin{array}{c}\text { Bacillus subtilis, Pseudomonas flourescens, } P \text {. } \\
\text { putida. } P \text {. aeruginosa, }\end{array}$ & Cucumber & $\begin{array}{l}\text { Root rot \& Crown rot } \\
\text { (42) }\end{array}$ \\
\hline 4 & Bacillus sp, Pseudomonas sp. & Melon & Powdery mildew(89) \\
\hline 5 & $\begin{array}{c}\text { Bacillus subtilis, B. amyloliquefaciens, } \\
\text { Pseudomonas aeruginosa }\end{array}$ & Cucumber & $\begin{array}{l}\text { Pythium damping-off } \\
\qquad(90)\end{array}$ \\
\hline 6 & $\begin{array}{c}\text { Bacillus sp, Pseudomonas fluorescens, P.putida, } \\
\text { Serratia marcescens }\end{array}$ & Cucumber & Fusarium wilt (91) \\
\hline 7 & Bacillus subtilis UMAF6639 & Cucurbit & Powdery mildew (92) \\
\hline 8 & Fluorescent pseudomonad CW2 & Cucumber & Wilt \& rot (93) \\
\hline 9 & Gliocladium catenulatum strain JI446 & $\begin{array}{l}\text { Vegetables, Herbs, } \\
\text { Spices }\end{array}$ & $\begin{array}{l}\text { Soil borne pathogens } \\
\text { (87) }\end{array}$ \\
\hline 10 & Pseudomonas fluorescence strain A506 & $\begin{array}{l}\text { Fruit crop, Tomato, } \\
\text { Potato }\end{array}$ & $\begin{array}{l}\text { Fire blight, bunch rot } \\
\text { (87) }\end{array}$ \\
\hline 11 & Streptomycine griseoviridis & $\begin{array}{l}\text { Ornamentals, Tree } \\
\text { seedlings }\end{array}$ & $\begin{array}{l}\text { Soil borne pathogens } \\
\text { (87) }\end{array}$ \\
\hline 12 & Trichoderma spp., & vegetables & Wilt and rot (94) \\
\hline 13 & Trichoderma spp., & $\begin{array}{l}\text { cucumber, bean, } \\
\text { tomato and onion }\end{array}$ & $\begin{array}{l}\text { Wilt, root rot, damping } \\
\text { off }(95)\end{array}$ \\
\hline 14 & Trichoderma spp., & cucumber & Fusarium wilt (96) \\
\hline 15 & $\begin{array}{l}\text { T. harzianum, T. viride and } \\
\text { T. hamatum }\end{array}$ & Tomato & Fusarium wilt (97) \\
\hline
\end{tabular}


The resistance to mildew and leaf infection by D. bryoniae of 28 melon genotypes was examined in the field. In the greenhouse, all 86 melon genotypes were showed infection after four days of inoculation. In field conditions and natural inoculation, genotypes Taslaki and Sary Juliabi were susceptible to leaf infection by $D$. bryoniae. All genotypes were susceptible to the downy mildew, albeit differing in susceptibility levels (74).

Melon fields surveyed in the California showed infection with vine decline or root rot. Among the pathogen isolated $A$. cucurbitacearum, $R$. vagnum, $M$. cannonballus, F. solani, Macrophomina phaseolina, Pythium spp., and Verticillium dahlia were the major from the field and were confirmed by their pathogenicity (75). The survey during late and early planting seasons was carried out in four states; 50 plants per farm were observed till the crop maturity and symptoms was observed from initiation to expression. Diseased leaf, stem, fruits and flower, samples were collected for identification of causal organisms. A total of 11 fungal species were isolated from the different fields namely Colletotrichum lagenarium, D. bryoaniae, Peronospora cubensis, Erysiphe cucurbitarum, Cercospora citrullina, A. cucumerina, A. niger, A. flavus, $F$. oxysporum, F. solani and R. stolonifer (76).

The survey of the vegetables at agricultural research extensions were made to know the diseases of the seedling and plants. The diseases recorded were damping-off, root-rot, white rot, wilt, downy and powdery mildews, early and late blights. The root rot pathogens isolated from the soil were Fusarium spp., $R$. solani, $S$. rolfsii in the high percentage. The genus Fusarium represented in highest records followed by genus Rhizoctonia and Sclerotium in all assayed samples. Pythium, Macrophomina and Sclerotinia are seen in a lesser frequency (77).
Pseudoperonospora cubensis ((Berkeley \& M. A. Curtis) Rostovzev), the causal agent of cucurbit downy mildew, is responsible for devastating losses worldwide of cucumber, cantaloupe, pumpkin, watermelon and squash. Angular chlorotic lesions bound by leaf veins on the foliage of cucumber. Symptoms vary on different cucurbit species and varieties, lesion development, shape, and size. Infection of cucurbits by Ps. Cubensis impacts fruit yield and plant health. Sporulation on the underside of leaves results in the production of sporangia that are dispersed by wind. On arrival on a susceptible host, sporangia germinate in free water on the leaf surface, producing biflagellate zoospores that swim to and encyst on stomata, where they form germ tubes. An appresorium is produced and forms a penetration hypha, enters the leaf tissue through the stomata. Hyphae grow through the mesophyll and establish haustoria, specialized structures for the transfer of nutrients and signals between host and pathogen $(78,79)$.

\section{Management}

All the positive resulted treatments used as the suitable treatments against these fungal pathogens of Cucurbits. In developing world, in order to control or minimize the diseases, use of chemicals (Table 2) in agriculture is prominent $(80,81)$. The plant growth promoting rhizobacteria (PGPR) (Table 3 ) and plant growth promoting fungi (PGPF) are at the present being used to control or minimize the pathogen (82). These can be used in place of chemical fertilizers and to enrich the barren land with nutrients. It is used as biocontrol agent against a variety of fungal diseases and some of them are even used as biofertilizers in agriculture to combat diseases and to supply the micronutrients to plants (83). Hybrid cultivars are commercialized in selected cucurbits, which express desirable heterosis for yield. In the case of melon, watermelon, cucumber and bottle gourd, several hybrid 
cultivars have been developed. Cucurbits are highly susceptible to several biotic and abiotic stresses. Resistance sources are generally present in landraces and wild relatives (32). Fumigation of infected field with methyl bromide can also be practiced. Suppression of soilborne pathogens can be achieved by intraspecific grafting and interspecific grafting (84). The use of soil fumigation and soil solarisation as a means for managing root and soilborne diseases was reported (85).

The crop losses may occur due to ecological, agronomical and biological factors. Among the biotic factors like pests and diseases, which are of prime importance, a wide range of fungal pathogens affecting the productivity of cucurbitaceae membersare included. Wilt and rot are the major soil borne fungal diseases caused by Fusarium spp., whereas damping-off is the result of Phytophthora spp., Acremonium spp. and Pythium spp. resulting up to $70 \%$ yield loss.

The moisture content of the seed, storage period, prevailing temperature and degree of seed invasion are the factors which influence the development of seed-borne fungi. The pathogen may be present either externally or internally or associated with the seed as a contaminant. It may cause seed abortion and rot necrosis, reduction / elimination of germination capacity as well as seedling damage at later stages of plant growth resulting in the development of the disease.

There are many approaches to control the disease like; use of resistant varieties, selection of suitable chemical fungicides and adoption of different cultural practices. The increase of soil borne disease makes the importance to search conventional and ecofriendly practices in the agriculture to control the pathogen. Among the biocontrol methods; the latest innovations, plant growth promoting rhizobacteria (PGPR) is the most widely catching up approach to control / deplete the pathogenic microbes and to control the plant yield losses.

In India, there are many reports on the management of cucurbit diseases; which include frequent use of chemicals and also selecting resistant varieties against the disease. Several field surveys pointed out that the major fungal diseases prevalent in the cucurbit growing area are wilt, root rot, leaf spot, blight, downy mildew and powdery mildew. To minimize the soil borne diseases and to improve the crop yield it is important to instruct farmers about the sustainable farming by using bio control agents.

\section{References}

1. Kundu S K, Spatio-temporal dynamics of vegetable crop production in India, International Multidisciplinary Research Journal, 2(7), 2012, $54-57$.

2. Egel D S, Martyn R D, Fusariums wilt of watermelon and other cucurbits, The Plant Health Instructor, DOI: 10.1094/PHI-I-20070122-01, Updated 2013.

3. FAOSTAT (online), 2010 - Food and Agriculture Organization of the United Nations - Rome, Italy, http://faostat.fao.org/default.aspx?lang=en.

4. Khanzada K A, Rajput M A, Shah G S, Lodhi A M, Mehboob F, - Effect of seed dressing fungicides for the control of seed borne mycoflora of wheat, Asian Journal of Plant Sciences1, 2002,441 - 444.

5. Bruton B A, Duthie J A, - Fusarium rot, In Compendium of Cucurbit Diseases, T A Zitter, D L

6. Hopkins, C E Thomas, eds American Phytopathological Society, St. Paul, MN,1996, 5051.

7. Koike S T, Gladder P, Paulus A O, Vegetable diseases-a colour handbook, London, UK. Manson Publishing Ltd, 2007,220-228.

8. Avinash $\mathrm{T}$ S, Rai V R, Identification of diverse fungi related with selected cucurbitaceae vegetables, Journal of Agricultural Technology 9(7), 2013, 1837- 
1848.

9. Neeraj, Verma S, Alternaria diseases of vegetable crops and new approaches for its control, Asian Journal of Experimental Biological Sciences, 1(3), 2010, 681-692.

10. Rahman AHMM, Anisuzzaman M, Ahmed F, Islam AKMR, Naderuzzaman ATM. Study of nutritive value and medicinal uses of cultivated cucurbits, Journal of Applied Sciences Research, 4(5), 2008, 555-558.

11. Rahaman ASH, Bottle gourd (Lagenaria siceraria) - A vegetable for good health, Natural Product Radiance, 2(5), 2003, 249256.

12. Jacks $T H$, Hensarling $T P$, Yatsu $L ~ Y$, Cucurbit seeds: I. Characterizations and uses of oils and proteins, a review, Economic Botany 26, 1972,135-141.

13. Rajeev K Y, Shalini S, Somesh Y, Pandey BN, Fungal Infection on Cucurbits and Climatic Factos, presented in procendings of Environmental Issues for Socio-ecological Development (eds: Dr. Rajendra Singh and Dr. Somesh Yadav), 2015,133-145.

14. Richardson M J, An annotated list of seedborne diseases. $4^{\text {th }}$ ed. International Seed Testing Association, Zurich, Switzerland, 1990, 320

15. Nair L N, Studies on mycoflora of seeds: some cucurbitaceous vegetables, Journal of Indian Botanical Socity, 61, 1982,342-345.

16. Mathur S B, Summaries of research project 1967-1988, Danish government institute of Seed Pathology for Developing Countries, Denmark, 1990, 111.

17. Donayre D K M, Minguez L T, Sensitivity of leaf spot causing pathogen of Bitter Gourd (Cooke) to different fungicides, Annals of Tropical Research 36(1), 2014, 75-87.

18. Furukawa T, Ono Y, Kishi K, Gummy stem blight of balsam pear caused by Didymellabryoniae and its anamorph Phoma cucurbitacearum, Journal of General Plant Pathology 73, 2007,125-128, DOI 10.1007/s10327-006-0336-2.

19. Sultana N, Ghaffar A, Seed borne fungi associated with bitter gourd (Momordica charantia Linn.), Pakistan Journal of Botany, 39, 2007, 2121-2125.

20. Khan F M, Amin M, Ullah Z, Rehman S, Amir M, Ali I, Distribution of Alternaria leaf spot of bitter gourd in district Peshawar and Nowshera, Khyber Pakhtunkhwa, Pakistan Journal of Pharmacognosy and Phytochemistry 3 (2), 2014,215.

21. Shakoor S, Chohan S, Riaz A, Perveen R, Naz S, Mehmood M A, Haider M S, Ahmad S, Screening of systemic fungicides and biochemicals against seed borne mycoflora associated with Momordica charantia. African Journal of Biotechnology 10(36), 2011, 69336940.

22. Sultana N, Ghaffar A, Pathogenesis and control of Myrothecium spp, the cause of leaf spot on bitter gourd (Momordica charantia Linn.),Pakistan Journal of Botany 41(1), 2009, 429-433.

23. Hwang $\mathrm{C} \mathrm{H}$, Lin $\mathrm{Y}$ S, Pan C M, Seedling blight of Bittergourd-loofah graft caused by Alternaria alternate f. sp. cucurbitae and its control in Taiwan, Plant protection bulletin 40, 1998,109-120.

24. Cumagun C J R, Aguirre J A, Relevante C A, Balatero $\mathrm{C} H, \quad-$ Pathogenicity and aggressiveness of Fusarium oxysporum Schl, in bottle gourd and bitter gourd, Plant Protection Science 46, 2010,51-58.

25. Gupta P, Singh T, - Bottle gourd seed infection by Fusarium oxysporum Schltdl, and its rolein disease development, Phytomorphology 59(1), 2009,57-60.

26. Sultana N, Gul M, Ghaffar A, - Survival of fungi on feeds of bottle gourd, bitter gourd and cucumber, Pakistan Journal of Botany 42, 2010, 1991-1997.

27. Bruton B D, Popham T W, Garcia-Jimenez J, Armengol J, Miller ME, Disease reaction among selected Cucurbitaceae to an Acremonium cucurbitacearum isolate from Texas, Hortscience 35(4), 2000, 677-680.

28. Garcia-Jimenez J, Velzazquez M T, Jorda C, Alfaro-Garcia A, Acremonium species as the causal agent of Muskmelon collspse in Spain, Plant Disease 78, 1994, 416-419.

29. Nurulhuda M S, Latiffah Z, Baharuddin S, Maziah Z, Diversity of Fusarium species from vegetable fruits, Malaysian journal of applied biology 38(1), 2009, 43-47.

30. Karaca G, Kahveci E, First report of Fusarium oxysporum f. sp. radicis-cucumerinum on cucumbers in Turkey, New Daisese Reports20,2009,9. 
31. Ko Y, Yao KS, Chen C Y, Lin C H, First Report of Gray Mold Disease of Sponge Gourd (Luffa cylindrica) Caused by Botrytis cinerea in Taiwan, Plant Disease 91(9), 2007,DOI: 10.1094/PDIS-91-9-1199A

32. Egel D S, Martyn R D, Fusarium wilt of watermelon and other cucurbits, The Plant Health Instructor, DOI: 10.1094/PHI-I-20070122-01, Updated 2013.

33. Rai M, Pandey S, Kumar S, Cucurbit research in India: a retrospect. Paper presented at Cucurbitaceae 2008, Proceedings of the IXth EUCARPIA meeting on genetics and breeding of Cucurbitaceae (Pitrat M, ed.), INRA, Avignon (France), May 21-24th, 2008.

34. Hamim I, Mohanto D C, Sarker M A, Ali M A, Effect of seed borne pathogens on germination of some vegetable seeds Journal of Phytopathology and Pest Management 1(1), 2014, 34-51.

35. Batta Y, Alternaria leaf spot disease on Cucumber: susceptibility and control using leaf disk assay, An-Najah University Journal of Research (Natural Science) 17(2),2003, 269-279.

36. Merkuri J, Varaku S, Casulli F, - Fungal diseases of vegetable crops in Albania, Phytopathologia Mediterranea,41, 2002, 157159.

37. Moreno A, Alferez A, Aviles M, Dianez F, Blanco R, Santos M, Tello J C, First Report of Fusarium oxysporum f. $\mathrm{sp}$. radiciscucumerinum on Cucumber in Spain. Plant disease 85 (11), 2001, 120.

38. Vatchev TzD, - First report of Fusarium root and stem rot of greenhouse cucumber caused by Fusarium oxysporum f.sp. radiciscucumerinum in Bulgaria, Bulgarian Journal of Agricultural Science 13, 2007,151-152.

39. Bafti S S, Bonjar G H S, Aghighi S, Biglari S, Farrokhi P R, Aghelizadeh A, Biological control of Fusarium oxysporum f. sp. melonis, the causal agent of root rot disease of greenhouse cucurbits in Kerman Province of Iran, American Journal of Biochemistry and Biotechnology 1(1), 2005,22-26.

40. Chehri K, Abbasi S, Reddy K R N, Salleh B, Occurrence and pathogenicity of various pathogenic fungi on cucurbits from Kermanshah province, Iran, African Journal of Microbiology Research4, 2010, 1215 - 1223.
41. Punja Z K, Parker M,- Development of Fusarium root and stem rot, a new disease on greenhouse cucumber in British Columbia, caused by Fusarium oxysporum f. sp. radiciscucumerinum, Canadian Journal of Plant Pathology, 2000, 349-363.

42. Mohamed Y F, Bardin M, Nicot P C, Pitrat M, - Causal agents of powdery mildew of cucurbits in Sudan. Plant Disease, 79, 1995,634-636.

43. Maleki M, Mokhtarnejad L, Mostafaee S, Screening of Rhizobacteria for biological control of cucumber root and crown rot caused by Phytophthora drechsleri, Plant Pathology Journal 27(1), 2011,78-84.

44. Hatami N, Aminaee M M, Zohdi H, Tanideh $\mathrm{T}$, Damping-off disease in greenhouse cucumber in Iran, Archives of Phytopathology and Plant Protection 46:7, 2013, 796-802. Kayani

45. M Z, Mukhtar T, Hussain M A, Haque M I, Perveen R, Incidence and severity of root-knot nematodes (meloidogyne spp.) on cucumber in district Rawalpindi, Pakistan Journal of Phytopathology 24(2), 2012,122-128.

46. Kayani M Z, Mukhtar T, Hussain M A, Haque M I, Ul-Haque M I, Infestation assessment of root-knot nematodes (Meloidogyne spp.) associated with cucumber in the Pothowar region of Pakistan. Crop Protection 47, 2013, 49-54.

47. Ismail M, Anwar S A, Riaz A, Incidence of Meloidogyne incognita in Cucumber Fields, Pakistan Journal of Zoology 44(5), 2012, 1383-1387.

48. Al-Sadi A M, Al-Said F A, Al-Kaabi S M, AlQuraini S M, Al-Mazroui S S, Al-Mahmooli I $\mathrm{H}$, Deadman M L, Occurrence, characterization and management of fruit rot of immature cucumbers under greenhouse conditions in Oman, Phytopathologia Mediterranea 50, 2011, 421-429.

49. Abdel-Kader M M, El-Mougy N S, Embaby E I, Lashin S M, Occurrence of Sclerotinia foliage blight disease of Cucumber and Pepper plants under protected cultivation system in I, Chemical and Biological Control Measures in Advances in Life Sciences 2(1), 2012,20-27.

50. El-Mougy N S, Abdel-Kader M M, Lashin S $\mathrm{M}$, Vegetables root rot disease management by an integrated control measures under 
greenhouse and plastic houses conditions in Egypt- A Review, International Journal of Engineering and Innovative Technology 3(5), 2013, 40-54.

51. Morsy S M, Drgham E A, Mohamed G M, Effect of garlic and onion extracts or their intercropping on suppressing damping-off and powdery mildew diseases and growth characteristics of Cucumber, Egyptian Journal of Phytopathology37(1), 2009,35-46.

52. Al-Sadia A M, Al-Masoudia R S, Al- Habsib N, Al-Saida F A, Al-Rawahyc S A, Ahmedc M, Deadman M L, Effect of salinity on pythium damping-off of cucumber and on the tolerance of Pythiumaphanidermatum, Plant Pathology 59, 2010,112-120.

53. Pandey K K, Pandey P K, Survey and surveillance of vegetable growing areas for prevalence of major diseases, Vegetable Science 30(2), 2003, 128-134.

54. Babadoost $\mathrm{M}$, Zitter $\mathrm{T}$ A, Fruit rots of Pumpkin: A serious threat to the pumpkin industry, Plant Disease 93(8), 2009,772-782.

55. Wyenandt C A, Riedel R M, Rhodes L H, Bennett M A, Nameth S G P, Survey of Fusarium spp. associated with fruit rot of pumpkin (Cucurbita pepo) in Ohio, Online, Plant Health Progress doi:10.1094/PHP-20100827-01-R, 2010.

56. Gannibal P B, Alternaria cucumerina causing leaf spot of pumpkin newly reported in North Caucasus (Russia), New Disease Reports 23, 2011,36 (doi:10.5197/j.20440588.2011.023.036).

57. Elmer W H, Covert S F, O'Donnell K, Investigation of an outbreak of Fusarium foot and fruit rot of pumpkin within the United States, Plant Disease 91, 2007,1142-1146.

58. Shishido M, Yoshida N, Usami T, Shinozaki T, Kobayashi M, Takeuchi T, Black root rot of cucurbits caused by Phomopsis sclerotioides in Japan and phylogenetic grouping of the pathogen, Journal of General Plant Pathology 72, 2006, 220-227.

59. Massoud M S, Survey of fungal diseases of some vegetables and fruits in Aswan, EGYPT, IOSR Journal of Pharmacy and Biological Sciences6(3), 2013, 39-42.

60. Bharath B G, Lokesh S, Raghavendra V B, Prakash H S, Shetty H S, First report of the occurrence of Myrothecium verrucariain watermelon seeds from India, Australasian Plant Disease Notes 1, 2006, 3-4.

61. Cabral C S, Henz G P, Moreira A J A, Reis, New cucurbitaceous hosts of Myrothecium roridum in Amazonas State, Brazil, Tropical Plant Pathology 34(6), 2009,402-405.

62. Russo VM, Russo BM, Cartwright B, Culture conditions affect colonization of watermelon by Colletotrichum orbiculare, Biologia Plantarum 44(2), 2001,305-307.

63. Jensen B D, First Report of Gummy Stem Blight Caused by Didymella bryoniae on Watermelon and Confirmation of the Disease on Pumpkin in Tanzania, Plant disease 95(6), 2011, 768.

64. Bharath B G, Lokesh S, Rai V R, Prakash H S, Yashovarma B, Shetty H S, Role of Foliar Spray in the Infection Biology and Management of Fungal Diseases of Watermelon (Citrullus lanatus (Thunb.) Matsum and Nakai), World Journal of Agricultural Sciences 1 (2), 2005, 105-108.

65. Alfaro-Fernandez A, Garcia-Luis A, Colonisation and histological changes in muskmelon and autumn squash tissues infected by Acremonium cucurbitacearum or Monosporascus cannonballus, European Journal of Plant Pathology 125, 2009, 73-85.

66. Kown M, Hong J, Cho B, Ki U, Kim K, A scab disease caused by Cladosporium cucumerinum on watermelon seedlings, Plant pathology journal 15(1), 1999, 72-75.

67. Vakalounakis D J, Doulis A G, Klironomou E, Characterization of Fusarium oxysporum f. sp. radicis-cucumerinum attacking melon under natural conditions in Greece,Plant Pathology54, 2005,339-346.

68. Fergany M, Kaur B, Monforte A J, Pitrat M, Rys C, Lecoq H, Dhillon NPS, Dhaliwal SS, Variation in melon (Cucumismelo) landraces adapted to the humid tropics of southern India, Genetic Resources and Crop Evolution 58, 2011,225-243.

69. Biernacki M, Bruton B D, Quantitative response of Cucumis melo inoculated with root rot pathogens. Plant Diseases 85, 2001,65-70.

70. Chilosi G, Reda R, Aleandri M P, Camele I, Altieri L, Montuschi C, Languasco L, Rossi V, Agosteo G E, Macri C, Carlucci A, Lops F, Mucci M, Raimondo M L, Frisullo S, Fungi associated with root rot and collapse of melon 
in Italy, Bulletin OEPP/EPPO Bulletin38, 2008, 147-154.

71. Cohen R, Pivonia S, Burger Y, Edelstein M, Gamliel A, Katan J, Toward Integrated Management of Monosporascus Wilt of Melons in Israel, Plant Disease 84(5), 2000,496-505.

72. Sudisha J, Kumar T V, Niranjana S R, Shetty HS, First report of gummy stem blight caused by Didymella bryoniae on muskmelon (Cucumis melo) in India, New Disease Reports9, 2004,7.

73. Choi I Y, Choi J N, Choi D C, Sharma P K, Lee $\mathrm{W} \mathrm{H}$, Identification and Characterization of the Causal Organism of Gummy Stem Blight in the Muskmelon (Cucumis melo L.), Mycobiology 38(3), 2010, 166-170. DOI:10.4489/MYCO.2010.38.3.166.

74. Gasparotto F, Vida J B, Tessmann D J, Alves T C A, Latent infection by Didymella bryoniae in muskmelon, Summa Phytopathologica, 37(1), 2011, 62-64.

75. Santos G R, Castro Neto M D, Ramos I N, Cafe-filho A C, Reis A, Momente V G, Peluzio J M, Ignacio M, Reaction of melon genotypes to the gummy stem blight and the downy mildew, Horticultura Brasileira27, 2009, 160-165.

76. Aegerter B J, Gorden T R, Davis R M, Occurrence and pathogenicity of fungi associated with melon root rot and vine decline in California, Plant Disease 84, 2000,224-230.

77. Kehinde I A, Characteristic symptoms of melon diseases caused by fungi in south western Nigeria, Research African Journal of Agricultural,8(46), 2000,5791-5801.

78. El-Mougy N S, Abdel-Kader M M, AbdelKareem F, Embabi E I, El-Mohamady R, Abd El-Khair $\mathrm{H}$, Survey of fungal diseases affecting some vegetable crops and their rhizospheric soilborne microorganisms grown under protected cultivation system in Egypt, Research Journal of Agriculture and Biological Sciences 7(2), 2011, 203-211.

79. Savory E A, Granke L L, Quesada-ocampo L M, Varbanova M, Hausbeck M K, Day B, The cucurbit downy mildew pathogen Pseudoperonospora cubensis, Molecular Plant Pathology, 2010,DOI: 10.1111/J.13643703.2010.00670.X
80. Lebeda A, Cohen Y. 2011 - Cucurbit downy mildew (Pseudoperonospora cubensis) biology, ecology, epidemiology, hostpathogen interaction and control. European Journal of Plant Pathology 129, 157-192.

81. Fravel D R, Deahl, K L, Stommel J R, Compatibility of the biocontrol fungus Fusarium oxysporum strain CS-20 with selected fungicides, Biological control, 34, 2005, 165-169.

82. Ramudu A C, Mohiddin J G, Srinivasulu M, Madakka M, Rangaswamy V, Impact of fungicides Chlorothalonil and Propiconazole on microbial activities in groundnut (Arachis hypogaea L.) Soils, ISRN Microbiology pp -7, 2005, doi:10.5402/2011/63404.

83. Whipps J M, Microbial interactions and biocontrol in the rhizosphere, Journal of Experimental Botany 52, 2001, 487-511.

84. Idris H A, Labuschagne N, Korsten L, Screening rhizobacteria for biological control of Fusarium root and crown rot of sorghum in Ethiopia, Biological Control40, 2007,97-106.

85. Cohen R, Burger Y, Horev C, Koren A, Edelstein $\mathrm{M}$, Introducing grafted cucurbits to modern agriculture, the Israeli experience, Plant disease 91(8), 2007, 916-923.

86. Tamietti G, Valentino D, Soil solarisation as an ecological method for the control of Fusrium wilt of melon in Italy, Crop Protection25, 2006,389 - 397.

87. Mathur S B, Kongsdal S O, Common laboratory seed health testing methods for detecting fungi, Danish government institute for developing countries, Copenhagen, Denmark, pp 2003, 357-364.

88. Jan M J, Nisar A D, Tariq A B, Arif H B, Mudasir A B, Commercial Biocontrol Agents and Their Mechanism of Action in the Management of Plant Pathogens.International Journal of Modern Plant \& Animal Sciences,1(2), 2013,39-57.

89. Zhao Q, Dong C, Yang X, Mei X, Ran W, Shen Q, Xu Y, Biocontrol of Fusarium wilt disease for Cucumis melo melon using bioorganic fertilizer, Applied Soil Ecology, 47, 2011,67-75.

90. Garcia-Gutierrez L, Romero D, Zeriouh H, Cazorla F M, Tores J A, de Vicente A, PerezGarcia A, Isolation and selection of plant growth-promoting rhizobacteria as inducers of 
systemic resistance in melon, Plant Soil 358, 2012, 201-212.

91. Elazzazy A M, Almaghrabi O A, Moussa T A A, Abdelmoneim T S, Evaluation of some plant growth promoting rhizobacteria (PGPR) to control Phytium aphanidermatum in cucumber plants, Life science journal 9(4), 2012,3147-3153.

92. Gul A, Ozaktan H, Kidoglu F, Tuzel Y, Rhizobacteria promoted yield of cucumber plants grown in perlite under Fusarium wilt Stress, Scientia Horticulturae 153, 2013, 2225.

93. García-Gutierrez L, Zeriouh H, Romero D, Cubero J, de Vicente A, Pérez-García A, The antagonistic strain Bacillus subtilis UMAF6639 also confers protection to melon plants against cucurbit powdery mildew by activation of jasmonate and salicylic aciddependent defence responses, Microbial Biotechnology6(3), 2013,264-274.

94. Salman M, Abuamsha R, Barghouthi S, Interaction of fluorescent Pseudomonads with
Pythium ultimum and Rhizoctonia solani in cucumber roots, American Journal of Experimental Agriculture, 3(1), 2013,240-251.

95. Woo SL, Scala F, Ruocco M, Lorito M, The molecular biology of the interactions between Trichoderma spp, phytopathogenic fungi, and plants Phytopathology 96, 2006, 181-185.

96. Haggag W M, Mohamed M E S, Biodiversity, Biological and Molecular Investigations of Biocontrol by the Genus Hypocrea/Trichoderma spp, European Journal of Scientific Research 65(2), 2011, 81-292.

97. Yang $X$, Chen L, Yong $X$, Shen Q, Formulations can affect rhizosphere colonization and biocontrol efficiency of Trichoderma harzianum SQR-T037 against Fusarium wilt of cucumbers, Biolo Fertil Soils 47, 2011,239-248.

98. Ojha S, Chatterjee N C, Mycoparasitism of Trichoderma spp, in biocontrol of fusarial wilt of tomato, Archives Of Phytopathology And Plant Protection 44, 8,2011, 771-782.

\section{How to cite this article:}

Thammaihraj Shanthi Avinash, H. P. Jai Shanker Pillai, Madhuri Biradar and Venkat M. Shinde. 2021. A Review on Fungal Diseases of Cucurbitaceae and their Management. Int.J.Curr.Microbiol.App.Sci. 10(08): 653-672. doi: https://doi.org/10.20546/ijcmas.2021.1008.075 